ACTA THERIOLOGICA

Vol. 27, 3: 45-59, 1982

\title{
Responses of Small Mammals to the Forest Management in the Białowieza Primeval Forest
}

\author{
Elżbieta WOŁK \& Krzysztof WOŁK
}

Wołk E. \& Wolk K., 1982: Responses of small mammals to the forest management in the Białowieża Primeval Forest. Acta theriol., 27, 3: 45-59 [With 4 Tables \& 6 Figs.]

Trapping of small mammals was carried out in the autumns of the period from 1976-1979 over 14 hectares of mixed coniferous forest of varyied age within the Białowieża Primeval Forest. The trapping lines ran along the boundaries and through the middle of each forest belt of the given age class. The oldest age classes of planted treestands and natural old-growth istand (over 100 years old) were characterized by a high similarity index of occurrence of mammals. The groups of mammals in the younger age classes of treestands and the narrow belt of old-growth stand are characterized by low indexes of similarity to mammals from ather classes and in relation to each other. This points to degradation of the narrow old stand belt as a habitat for mammals. Succession of mammals in a complete clearing lasts for a shorter time than attainment of maturity by the tree stand and ends in the 20-year old treestand. This takes place in two phases. A. 1 to 14 years as from time of planting the clearing: the number of mammal species and numbers of mammals increase (at the beginning almost zero) to a maximum in the $11-14$ year old treestand. B. 15 to approx. 20 years: non-forest species disappear, and quantitative proportions for different species of mammals, typical of an old coniferous forest, are formed. The following four species of mammals were found in the natural old coniferous stand: Clethrionomys glareolus, Sorex araneus, Sorex minutus and Apodemus flavicollis.

[Mammals Res. Inst., Polish Acad. Sci., 17-230 Białowieża (EW) and Forest Res. Inst., Nature Prot. Res. Section, 17-230 Białowieża (KW)].

\section{INTRODUCTION}

Several factors induced the authors to undertake these studies. (1) There is a need to document the structure of groups of small mammals in the current and very specific stage of economic management of tree stands in the Białowieża Primeval Forest. Since the last war human activities have created three basic types of treestand in the Forest, on an almost landscape scale: woods used for a specific purpose, without clear cutting in the part belonging to the Soviet Union, the Białowieża National Park in Poland under state protection as a nature reserve (supplemented by a network of reserves) and treestands under forest management. Within the immediate future felling of old treestands with 
natural characteristics will cease in the part of the Białowieża Primeval Forest under management, and consequently for a period of many years no new plantations and young tree areas will be formed. (2) As the result of the system of clearcutting used in the Białowieża Primeval Forest, clearing in turn belts of timber stand adjoining each other and subsequently successively planting these belts, coniferous tree stands of various age have been created. The distribution of these adjacent age classes makes it possible on the one hand to trace succession of mammals in clearings, and on the other to determine what disturbances in mammal fauna are caused by this type of management. (3) The fauna of coniferous stands in the Białowieża Primeval Forest is relatively little known, since chiefly deciduous stands have been examined (e.g., Aulak, 1970).

\section{DESCRIPTION OF THE STUDY TREESTANDS}

The study area is situated in coniferous woods under management, which cover about $10 \mathrm{~km}^{2}$ of the Białowieża Primeval Forest. Diversity in age of stands in the managed part of the Forest is a general feature. The old-growth stand is used by clear cutting from $2-4$ ha in area. Such clearings are made every 5-7 years, and are situated successively in the neighbourhood of the previous cutting, which is usually afforested the same year with very small trees, chiefly pine and spruce, with a certain number of deciduous species. The series of belts of planted tree stands of varying age, running $\mathrm{N}-\mathrm{S}$, were created in this way, to make way for which part of the natural old stand disappears from the east every few years (Fig. 1). The old stand, which previously covered the whole study area, has characteristics of a primeval forest and was formed by self-sowing. This is the bilberry pine forest Vaccinio myrtilli-Pinetum, changing gradually in the southern part to cowberry pine forest Vaccinio vitis-idaeae-Pinetum. It is a multi-layered treestand with marked predominance of pine from $110-120$ years old and slightly younger spruce. Betula verrucosa occurs singly. The proportion of spruce in the lower layers of the treestand is slightly greater, and it is the chief component of the undergrowth. Description of the habitat included the herb layer, since this is a layer of fundamental importance to small mammals (Miller \& Getz, 1977). A description of the study treestands is given in Table 1. The marginal line of traps no. 15 ran along the edge of the youngest plantation which neighboured the older plantation (about 10 years old) almost identical with that adjoining the old stand (trapping line no. 4). Description of neighbouring treestands include habitat descriptions of other ecotone trapping lines (nos. 3, 5, 7, 9, 11, 13) (Fig. 1).

\section{METHODS}

The small mammals were caught in traps which operated each year for 10-day periods from 13-22.9.1976, $7-16.9 .1977, \quad 14-23.9 .1978$ and 18-27.9.1979. Trapping was carried out in a 14 ha mixed coniferous wood of varying age, on 105 sites, on each of which two traps were set: a pitfall and a snap-trap (Fig. 1). This 
area had previously been permanently marked with stakes, bearing letters and numbers distributed in younger treestands in lines along the boundaries and the middle of a forest belt of given age class, and in the old stand by a grid of squares with $40 \mathrm{~m}$ sides. By preparing the area in this way it was possible to ensure identical placing of traps in repeats. In 1976 trapping of mammals was carried out only along lines running down the middle of treestand belts of different age classes. As from 1977, in which complete clearings were made in part of the study area, up to the end of the study period, i.e. to 1979 , captures were

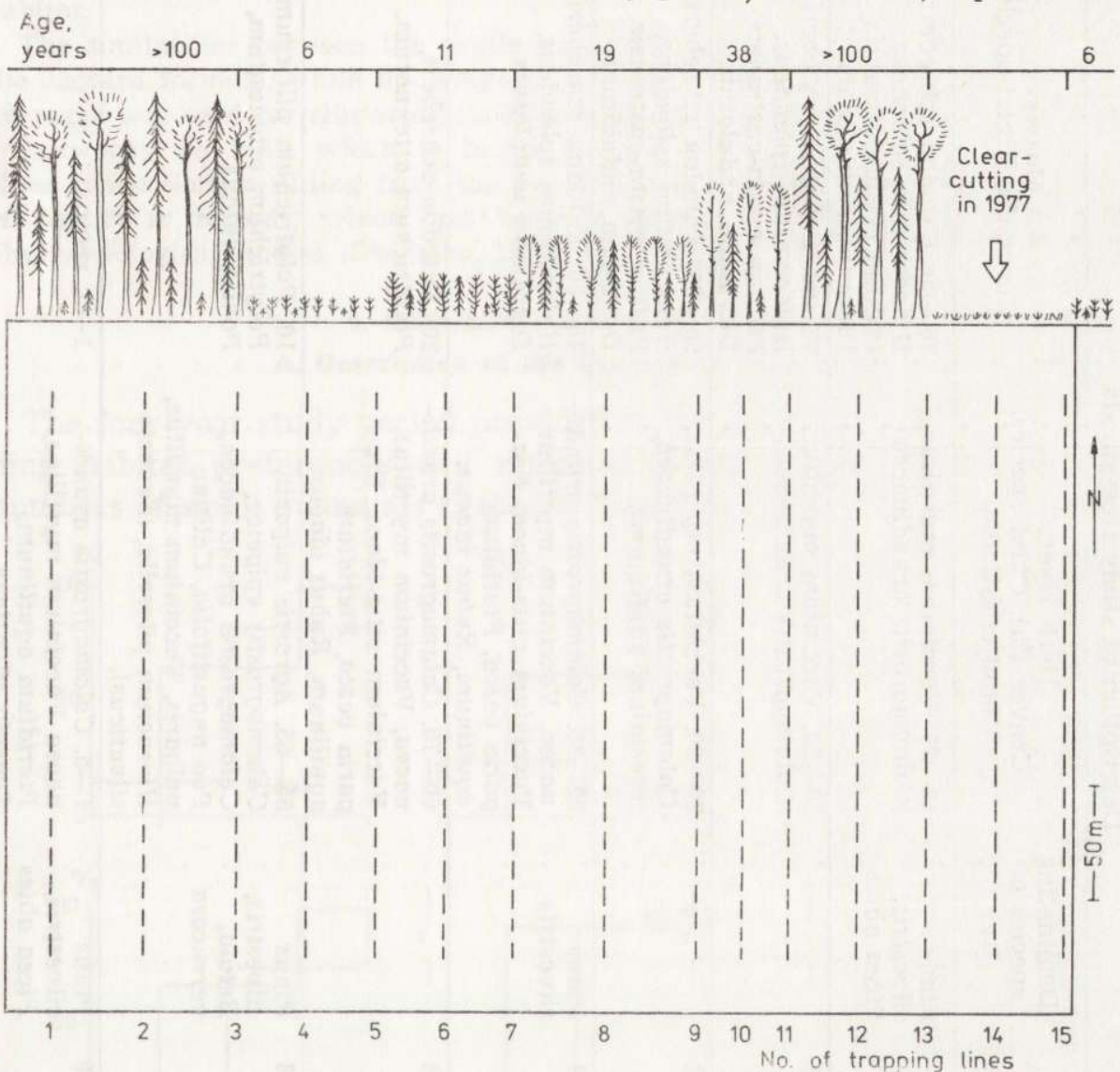

Fig. 1. Diagram of the capture area in six seral stages in a coniferous forest.

made both along the middle and the boundaries of treestands in different age classes, keeping to the identical number of trapping points over the whole study area (Fig. 1).

Belts of treestands in different age classes were about $540 \mathrm{~m}$ in length, while trapping lines were $300 \mathrm{~m}$ long. The coniferous forest adjoining the study area had stands of similar structure. The traps were inspected once daily, and the mammals caught were given standard examination in the laboratory to establish species, age and sex. 


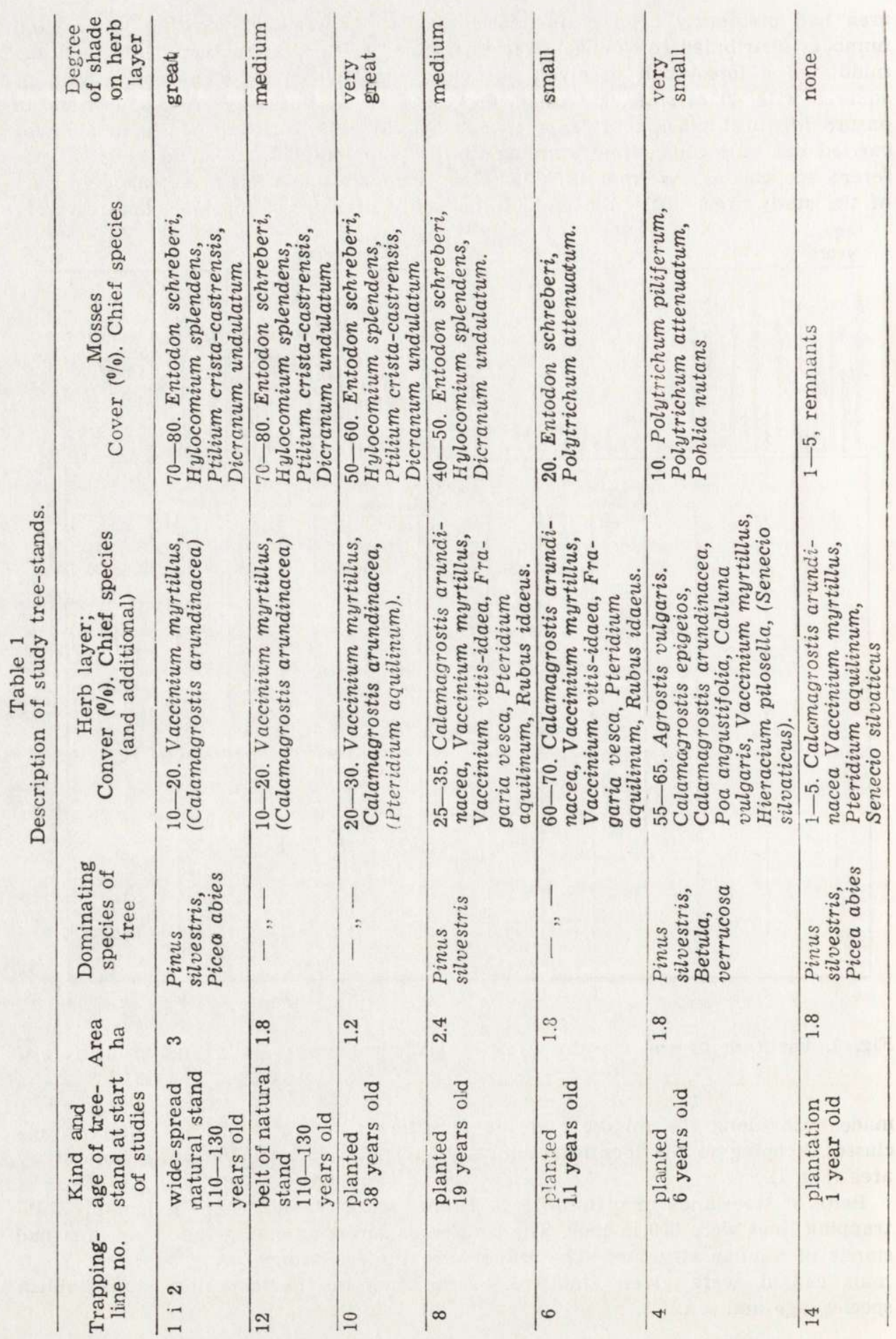




\section{B. ANALYSIS OF THE MATERIAL}

In order to examine the relative numbers of mammals calculation was made of the trappability indexes for each trapping line (number of captures/100 trapping days). The numbers of mammals caught in the old stand by means of two trapping lines (nos. 1 and 2) did not significantly differ ( $t$ Student test), and thus the trapping results may be considered as a representative sample for the given habitat.

The similarities between the single trapping lines were calculated by means of the Jaccard formula, while the weighted pair-group method employing arithmetical averages was used for clustering (Sneath \& Sokal, 1973). In this way a hierarchical system may be built which is based on similarities, distances, correlations or other connections resulting from the use of a mathematical model for comparisons of particular records, which has been successfully employed in, for instance, phytosociological studies (Dzwonko, 1977).

\section{RESULTS AND DISCUSSION}

\section{A. Description of the Occurrence of Species}

The four-year study period provided date which permitted of determining habitat preferences and interspecies differences in variations in numbers of small mammals (Table 2, Figs 2 and 3).
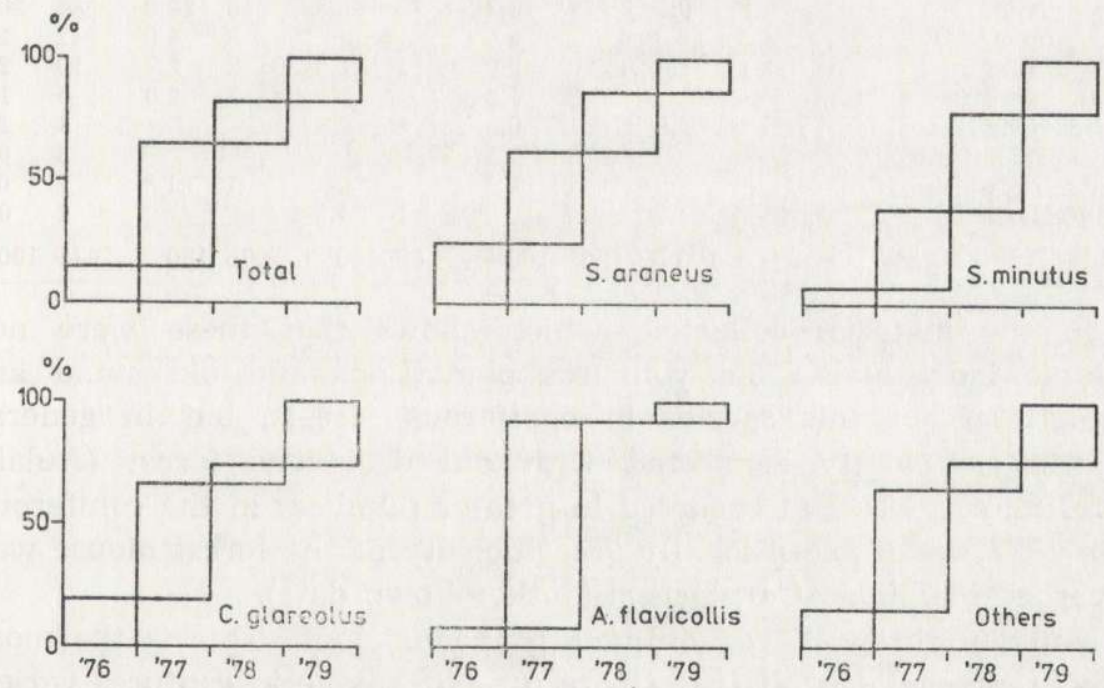

Fig. 2. Percentage of species of small mammals in captures from 1976-1979.

The bank vole, Clethrionomys glareolus (Schreber, 1780). This is usually the most numerous species, its percentage in captures varying from $13-40 \%$. It is the dominating species in the old stand, although during the year of population depression it did not occur at all (Fig. 3). The factor determining its numbers is undoubtedly the occurrence and 
development of the succulent components of the herb layer, which are fewer in number in the clearing and youngest plantations, and are replaced by mosses in the old stand. According to Hansson (1978) the bank vole occurs most numerously in Sweden in 30-year old forests with moderate vegetation ground cover. Similar data were obtained by Banach et al. (1980).

The yellow-necked field mouse, Apodemus flavicollis (Melchior, 1834). This is a species characterized by varying numbers. In 1977 in which there was an exceptional increase in the numbers of this species, the forest mouse dominated in the mammal community $(36 \%)$, but did not occur the following year, while in the remaining study years its percentage was from $8-11 \%$. No gestating or lactating females were

Table 2

Small mammals caught in 1976-1979.

\begin{tabular}{|c|c|c|c|c|c|c|c|c|c|c|}
\hline \multirow{2}{*}{ Species } & \multicolumn{2}{|c|}{1976} & \multicolumn{2}{|c|}{1977} & \multicolumn{2}{|c|}{1978} & \multicolumn{2}{|c|}{1979} & \multicolumn{2}{|c|}{ Total } \\
\hline & $\mathrm{N}$ & $\%$ & $\mathrm{~N}$ & $\%$ & $\mathrm{~N}$ & $\%$ & $\mathrm{~N}$ & $\%$ & $\mathrm{~N}$ & $\%$ \\
\hline Clethrionomys glareolus & 22 & 34.9 & 54 & 26.3 & 9 & 13.2 & 30 & 40.0 & 115 & 28.0 \\
\hline Sorex araneus & 22 & 34.9 & 33 & 16.1 & 22 & 32.3 & 12 & 16.0 & 89 & 21.6 \\
\hline Apodemus flavicollis & 7 & 11.1 & 73 & 35.6 & - & & 6 & 8.0 & 86 & 20.9 \\
\hline Sorex minutus & 6 & 9.5 & 27 & 13.2 & 33 & 48.5 & 18 & 24.0 & 84 & 20.4 \\
\hline Microtus arvalis & 4 & 6.3 & 5 & 2.4 & - & & 3 & 4.0 & 12 & 2.9 \\
\hline Microtus agrestis & 1 & 1.6 & 6 & 2.9 & 1 & 1.5 & 2 & 2.7 & 10 & 2.4 \\
\hline Micromys minutus & - & & 2 & 1.0 & - & & 3 & 4.0 & 5 & 1.2 \\
\hline Sicista betulina & 1 & 1.6 & 1 & 0.5 & 2 & 2.9 & - & & 4 & 1.0 \\
\hline Apodemus sylvaticus & - & & 3 & 1.5 & - & & - & & 3 & 0.7 \\
\hline Apodemus agrarius & - & & 1 & 0.5 & - & & 1 & 1.3 & 2 & 0.5 \\
\hline Neomys fodiens & - & & - & & 1 & 1.5 & 一 & & $\overline{1}$ & 0.2 \\
\hline Total & 63 & 100 & 205 & 100 & 68 & 100 & 75 & 100 & 411 & 100 \\
\hline
\end{tabular}

found in the material collected, which shows that these were not autochtonic individuals. The youngest plantations and old stand are typical habitats of this species in coniferous forests, but in general this species is closely connected with old deciduous forest (Aulak, 1970; Hoffmeyer, 1973). It occurred in greater numbers in the coniferous forest in 1977, when exceptionally great density of the forest mouse was also recorded in Tilio - Carpinetum (authors' own data).

The common shrew, Sorex araneus Linnaeus, 1758. This is the most numerous representative of Insectivora. Its percentage in captures varied from $16-35 \%$. The common shrew's optimal habitats are young treestands from 11-22 years old (Fig. 3). The numbers of this species were markedly lower in 1979.

The pigmy shrew, Sorex minutus (Linnaeus, 1766). In the last two study years its numbers were greater than that of the common shrew, its percentage in captures varying from 9 to $48 \%$. The pigmy shrew's optimum habitat in the coniferous stands are young, 11-22 year old 
treestands. The numbers of this species were distinctly lower in 1976 .

The field vole, Microtus agrestis (Linnaeus, 1761). This species inhabits young tree plantations, its percentage in the community structure being from $2-3 \%$. It is a species alien to natural old coniferous forests. According to Hansson (1978) its habitat requirements are very similar to those of $S$. araneus, but shrews are more common in dense treestands. Both gestating and lactating females were found among the animals caught, this also applying to the next species, the common vole. This provides some proof of the settled nature of voles in treestands in the younger age classes.

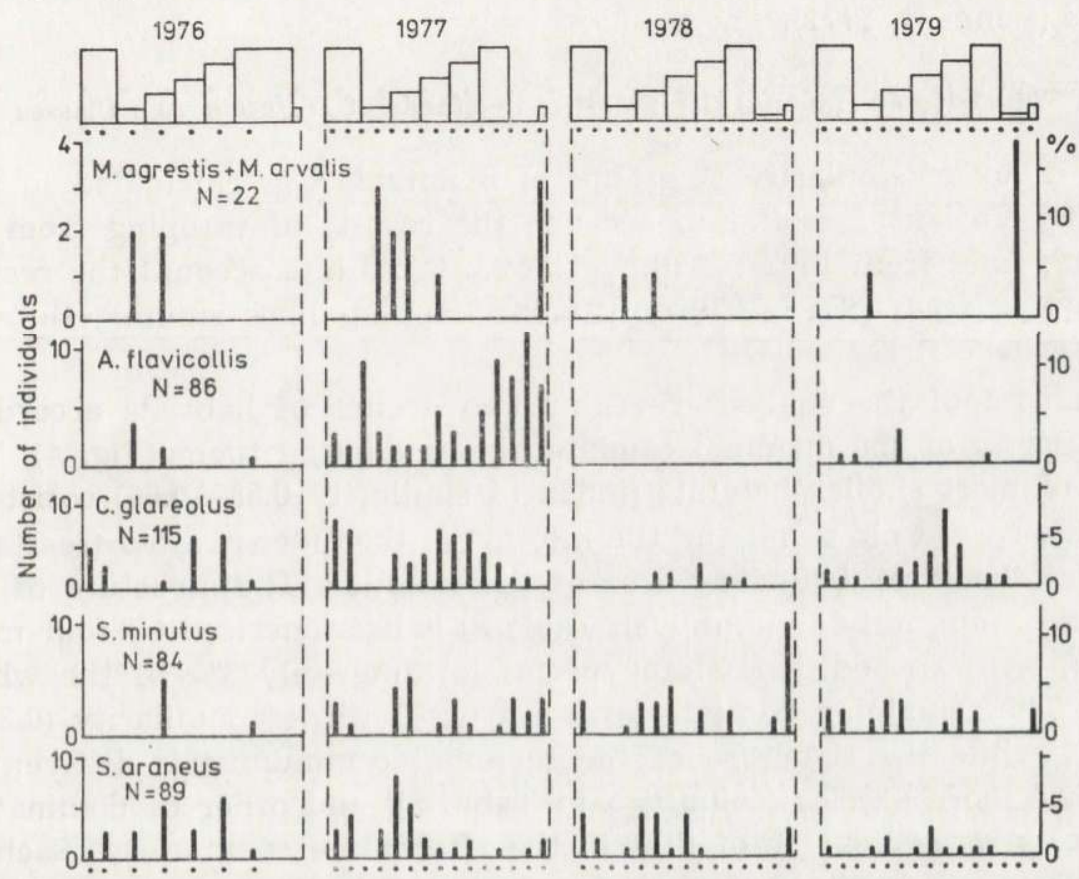

Fig. 3. Number of individuals of different selected species caught from 1976-1979. Sketch of forest stands at the top. Dots - localities of trapping lines 1-15 (see Fig. 1).

The common vole, Microtus arvalis (Pallas, 1779). The numbers of this vole vary to a greater degree than those of the field vole, and it was not found at all in 1978. It was most often caught in the youngest plantations from $2-9$ years old.

The wood mouse, Apodemus sylvaticus (Linnaeus, 1758). The three males caught in 1977 in the youngest plantation of the study area were the first representatives of this species to be caught in the Białowieża Primeval Forest (Wołk \& Wołk, 1979). Additional trapping carried out in the immediate vicinity yielded a further 12 individuals in the autumn 
of the same year. The mice caught, which belonged to the II $-\mathrm{V}$ age classes included two lactating females, which points to the settled nature of their presence. This species was not found again in subsequent years. The wood mouse prefers the edges of forests or thickets, and is considered as a species which needs less dense ground cover than is the case with A. flavicollis (Hoffmeyer, 1973).

The birch mouse Sicista betulina (Pallas, 1778), and harvest mouse Micromys minutus (Pallas, 1778) proved to be species sporadically occurring in the coniferous stands examined, while species which were clearly incidental were Apodemus agrarius (Pallas, 1771) and Neomys fodiens (Pennant, 1771).

\section{B. Similarity of Mammal Communities in Stands of Different Age Classes}

The index of similarity in groups of mammals was calculated in two variants. Variant 1 took into account the results of trapping from all trapping lines from 1977-1979. Variant 2 takes into account the results of trapping from 1976-1979 only from trapping lines running through the interior of treestands.

Variant 1 of the analysis revealed two groups of habitats according to similarity of the mammal communities inhabiting them (Fig. 4). The group of most similar habitats (index of similarity 0.58-0.66) cosists of the wide-spread old stand and the interior of the older planted treestand, and also the inner boundary area of these stands. The structure of the mammal community (column $a$ in Table 3 ) is characterized by four main species, with an additional four species forming only $3 \%$ of the whole group. The remaining habitats form a group with less similarity $(0.38-$ -0.58), while the structure of the mammal community is differentthere are more species (column $b$ in Table 3), and order of domination of species is the reverse of that in the alternative community. Each of these groups of habitats occupies two parts of the study area (cf. Figs 1 and 4), each forming an area of approximately 7 ha. The relative density of mammals in the two groups of habitats is similar (differences in the trappability index checked by the $t$ Student test are not significant).

Variant 2 of the analysis also distinctly separated data into two groups (Fig. 4). The first group, with a high index of similarity $(0.67-0.78)$ includes data from trapping lines in the old wide-spread stand and the two oldest age classes of planted woods, while the second includes the remaining habitats which were not very similar (Fig. 4). As in variant 1, the first group of habitats was characterized by the smaller number of species occurring there (Table 3).

Both variants of the analysis of similarity of mammal communities 

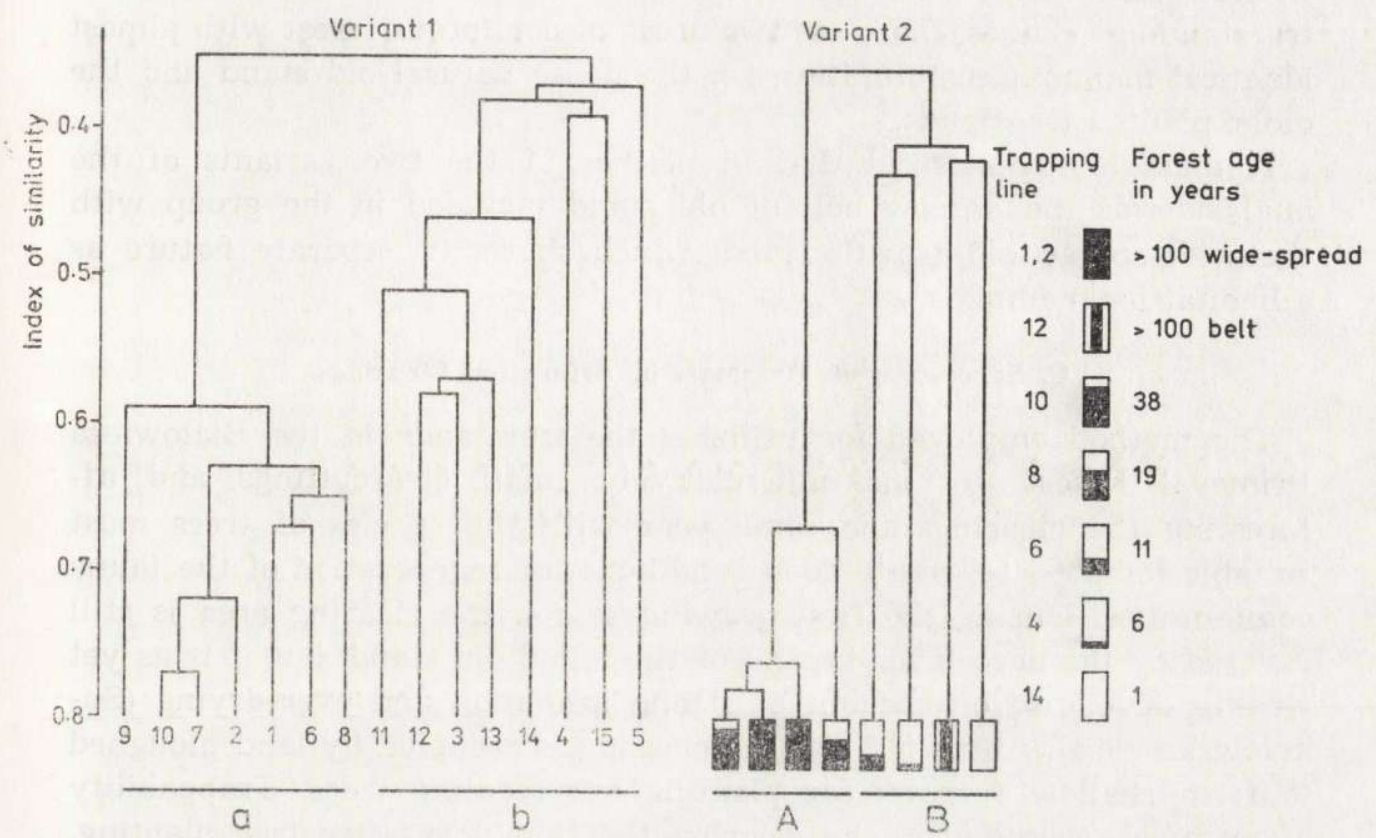

Fig. 4. Similarity of environments in relation to number and community composition of small mammals caught on all trapping lines (Variant 1) and on trapping lines running through the middle of the forest stands (Variant 2). See text for explantations.

Table 3

Number of individuals of different species trapped in groups of similar environments.

\begin{tabular}{|c|c|c|c|c|c|c|c|c|}
\hline \multirow{3}{*}{ Species } & \multicolumn{8}{|c|}{ Groups of environments - see Fig. 4} \\
\hline & & a & & & & A & & \\
\hline & $\mathrm{N}$ & $\%$ & $\mathrm{~N}$ & $\%$ & $\mathrm{~N}$ & $\%$ & $\mathrm{~N}$ & $\%$ \\
\hline Clethrionomys glareolus & 74 & 41.8 & 19 & 11.1 & 60 & 46.9 & 15.3 & 12.1 \\
\hline Sorex araneus & 40 & 22.6 & 27 & 15.8 & 38 & 29.7 & 24.3 & 20.0 \\
\hline Sorex minutus & 35 & 19.8 & 43 & 25.1 & 15 & 11.7 & 24 & 19.0 \\
\hline Apodemus flavicollis & 23 & 13.0 & 56 & 32.7 & 13 & 10.2 & 39.7 & 31.4 \\
\hline Microtus agrestis & 2 & 1.1 & 7 & 4.1 & 1 & 0.8 & 5.3 & 4.2 \\
\hline Sicista betulina & 1 & 0.6 & 2 & 1.2 & 1 & 0.8 & - & \\
\hline Microtus arvalis & 1 & 0.6 & 7 & 4.1 & - & & 11 & 8.7 \\
\hline Apodemus agrarius & 1 & 0.6 & 1 & 0.6 & - & & 2 & 1.6 \\
\hline Micromys minutus & - & & 5 & 2.9 & - & & 3.7 & 2.9 \\
\hline Apodemus sylvaticus & - & & 3 & 1.7 & - & & 1.3 & 1.0 \\
\hline Neomys fodiens & - & & 1 & 0.6 & - & & - & \\
\hline Total & 177 & 100 & 171 & 100 & 128 & 100 & 126.6 & 100 \\
\hline
\end{tabular}

1 Numbers of mammals caught on trapping line no. 14 (plantation on clearing) calculated by adding average values found for 1977-1979, instead of missing data for 1976 . 
showed that out of the whole study area, with belt distribution of treestand age classes, there are two areas of coniferous forest with almost identical mammal communities, i.e. the dense natural old stand and the older planted treestands.

It must be emphasized that in neither of the two variants of the analysis was the narrow belt of old stand included in the group with the wide-spread old-growth stand, which shows its separate nature as a habitat for mammals.

\section{Succession of Mammals in Afforested Clearings}

The method employed for utilizing the treestands in the Białowieża Primeval Forest, by making relatively small clearcuttings and afforesting the clearings the same year with the species of trees most suitable for the site, create good conditions for regeneration of the fauna communities. During the first growing season the clearing area is still covered by the herb layer typical of the felled old stand, but it is as yet weakly developed on account of strong insolation and over-drying (Sokołowski, 1961). About $50 \%$ of the clearing is occupied by land ploughed to form shallow furrows for planting out seedling trees. Trappability of mammals was low in the clearing the first year after tree planting, and there were no individuals taking part in reproduction. During the time in which the studies were carried out, an additional 20 snap-traps were placed on the new clearing near the study area. Not a single mammal was caught for 6 days. It may therefore be concluded that small mammals cannot find suitable living conditions in the coniferous forest clearing. In subsequent years a herb layer develops with the species composition characteristic of treeless areas. The youngest plantation (1-3 years) is characterized by a mammal community with the lowest percentage of insectivores, among which $S$. minutus dominates (Table 4, Fig. 5). The greatest percentage there is formed by granivore-omnivores (about $70 \%$ ), represented by 4 species and it was only there that the wood mouse $A$. sylvaticus was found. $M$. arvalis, a typical field rodent, settled there. The habitat most abundant in mammals is the young tree stand from 11-14 years old: it was here that a record trappability index of 7.71 was found and the greatest number of species. Insectivores dominate in the community and there form the highest percentage and the highest trappability index (Table 4), while granivores-omnivores form the smallest percentage. In the next age class (19-22 years) the percentage of voles continues to decrease (only $M$. agrestis occurring there in small numbers) and the percentage of A. flavicollis and C. glareolus (granivore-omnivores) increases. There are no voles in the treestand from 38-41 years old, while the proportions between grani- 


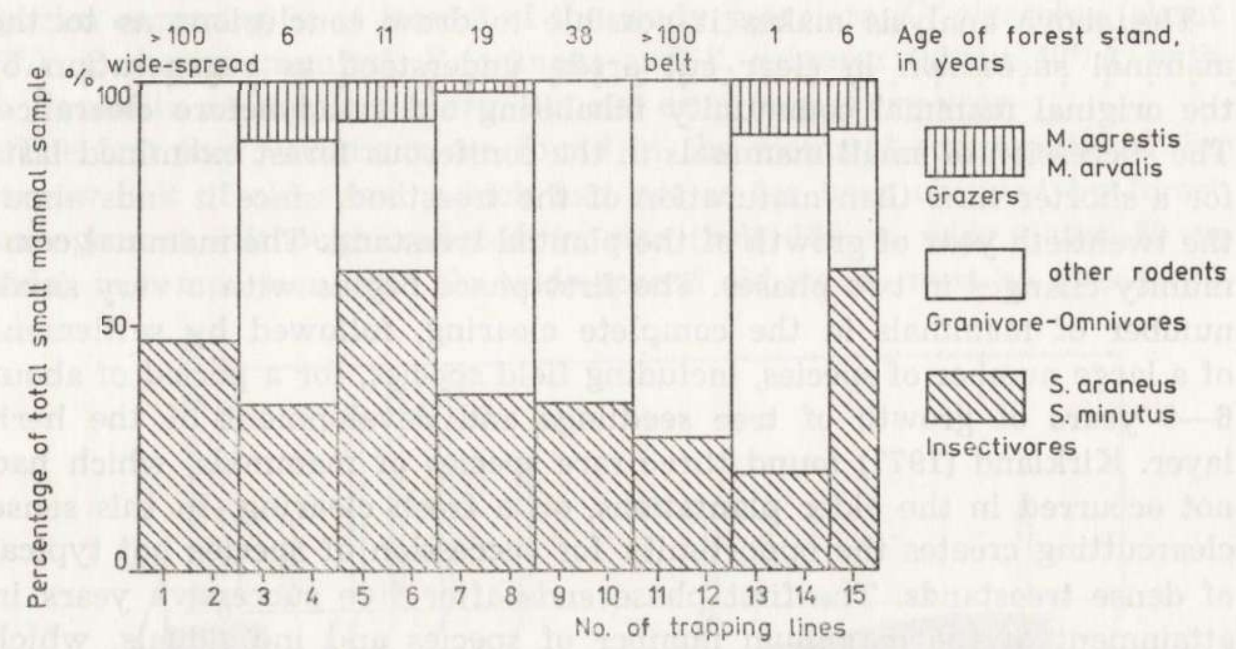

Fig. 5. Small mammal community composition of three trophic groups in coniferous stands of different age.

vore-omnivores and insectivores undergo no significant change. The number of species, which was 6 in the previous age class, continues to decrease and reaches a minimum of 4 . The same number of species occurs and identical species composition occur in the dense treestand over 100 years old. These species are: C. glareolus (most numerous), $S$. araneus, S. minutus and, least numerous, A. flavicollis. The trappability index in the last three age classes of treestand is similar, but is lowest in the old coniferous forest (4.23).

Table 4

Relative abundance of small mammals (trappability index) in coniferous forest stands of different age.

\begin{tabular}{lcccccccc}
\hline Forest age in years & $>100^{1}$ & 6 & 11 & 19 & 38 & $>100^{2}$ & 1 & $1 / 6^{3}$ \\
\hline Sorex araneus & 1.25 & 0.70 & 2.37 & 1.23 & 1.05 & 0.35 & 0.12 & 1.19 \\
Sorex minutus & 0.76 & 0.44 & 2.37 & 0.53 & 0.79 & 0.53 & 0.71 & 3.33 \\
Neomys fodiens & - & 0.09 & - & - & - & - & - & - \\
Sicista betulina & - & - & 0.17 & 0.17 & - & - & - & - \\
Micromys minutus & - & 0.09 & 0.17 & - & - & - & 0.24 & - \\
Apodemus agrarius & - & 0.09 & 0.09 & - & - & - & - & - \\
Apodemus sylvaticus & - & - & - & - & - & - & 0.36 & 0.48 \\
Apodemus flavicollis & 0.42 & 1.49 & 0.79 & 0.61 & 0.44 & 1.40 & 2.26 & 1.67 \\
Clethrionomys glareolus & 1.80 & 0.09 & 1.14 & 2.28 & 3.07 & 0.96 & 0.36 & - \\
Microtus agrestis & - & 0.17 & 0.35 & 0.09 & - & - & 0.12 & 0.24 \\
Microtus arvalis & - & 0.35 & 0.26 & - & - & - & 0.36 & 0.48 \\
\multicolumn{1}{c}{ Total } & 4.23 & 3.51 & 7.71 & 4.91 & 5.35 & 3.24 & 4.53 & 7.39 \\
\hline Total trap-nights & 1440 & 1140 & 1140 & 1140 & 1140 & 1140 & 840 & 420 \\
Number of species & 4 & 9 & 9 & 6 & 4 & 4 & 8 & 0 \\
\hline
\end{tabular}

${ }^{1}$ Wide-spread; ${ }^{2}$ Belt; ${ }^{3}$ Border line between 1 and 6 years old plantations. 
The above analysis makes it possible to draw conclusions as to the mammal succession in clear cut areas, understood as regeneration of the original mammal community inhabiting old stand before clearance. The succession of small mammals in the coniferous forest examined lasts for a shorter time than maturation of the treestand, since it ends about the twentieth year of growth of the planted treestand. The mammal community changes in two phases. The first phase begins with a very small number of mammals in the complete clearing, followed by settlement of a large number of species, including field species, for a period of about 6-9 years of growth of tree seedlings and development of the herb layer. Kirkland (1977) found three rare species of mammals, which had not occurred in the older plantations, on a fresh clearing. In this sense clearcutting creates the opportunity for succession of species not typical of dense treestands. The first phase ends after five successive years in attainment of the maximum number of species and individuals, which is probably connected with maximum development of the herb layer (Fig. 6). The second phase of the succession of small mammals, undoubtedly chiefly connected with increase in the shadiness of the forest floor, takes place about the 15th year, and consists in disappearance of species proper to the first phase of succession and formation of quantitative proportions of the different species found in old coniferous forests, ending about the twentieth years of the forest's growth.

In Grodziński's studies (1957) on the secondary succession of coniferous forests, a group with the same composition as in the control plots in the old treestand formed as early as in the young tree plantation. This author describes certain general regularities which agree with the results of our studies. Similar regularities were observed by Kirkland (1977) in studying the community and population responses of small mammals to clearcutting. The first reaction to clearcutting observed by this author was increase in trappability, density, differentiation of the community and shifts in the relative numerousness of species and trophic groups. Changes in the relative numbers of insectivores were generally smaller than in grazers and granivore-omnivorous rodents (Kirkland, 1977). This points to the decisive role of trophic factors in regeneration of the mammal community typical of the old forest, since it is these groups of mammals which are exposed to the greatest variations in the food supply of the habitat due to utilization of the forest.

\section{RECAPITULATION}

The most striking feature of small mammalian fauna in a mature mixed coniferous stand in the Białowieża Primeval Forest is the small number of species (4) and small numbers of individuals found there, 
Species occurring in at least 3 of the study years are: C. glareolus (about $47 \%$ of the community), $S$. araneus and $S$. minutus (about $40 \%$ ), with $A$. flavicollis as supplementary, but not occurring every year.

The fact that variations are found in the mammal community of the narrow belt of old stand, which had not so far been changed by forest management, although reduced in size (belt $120 \mathrm{~m}$ wide, later $60 \mathrm{~m}$ wide), in comparison with the wide-spread old stand, must be considered

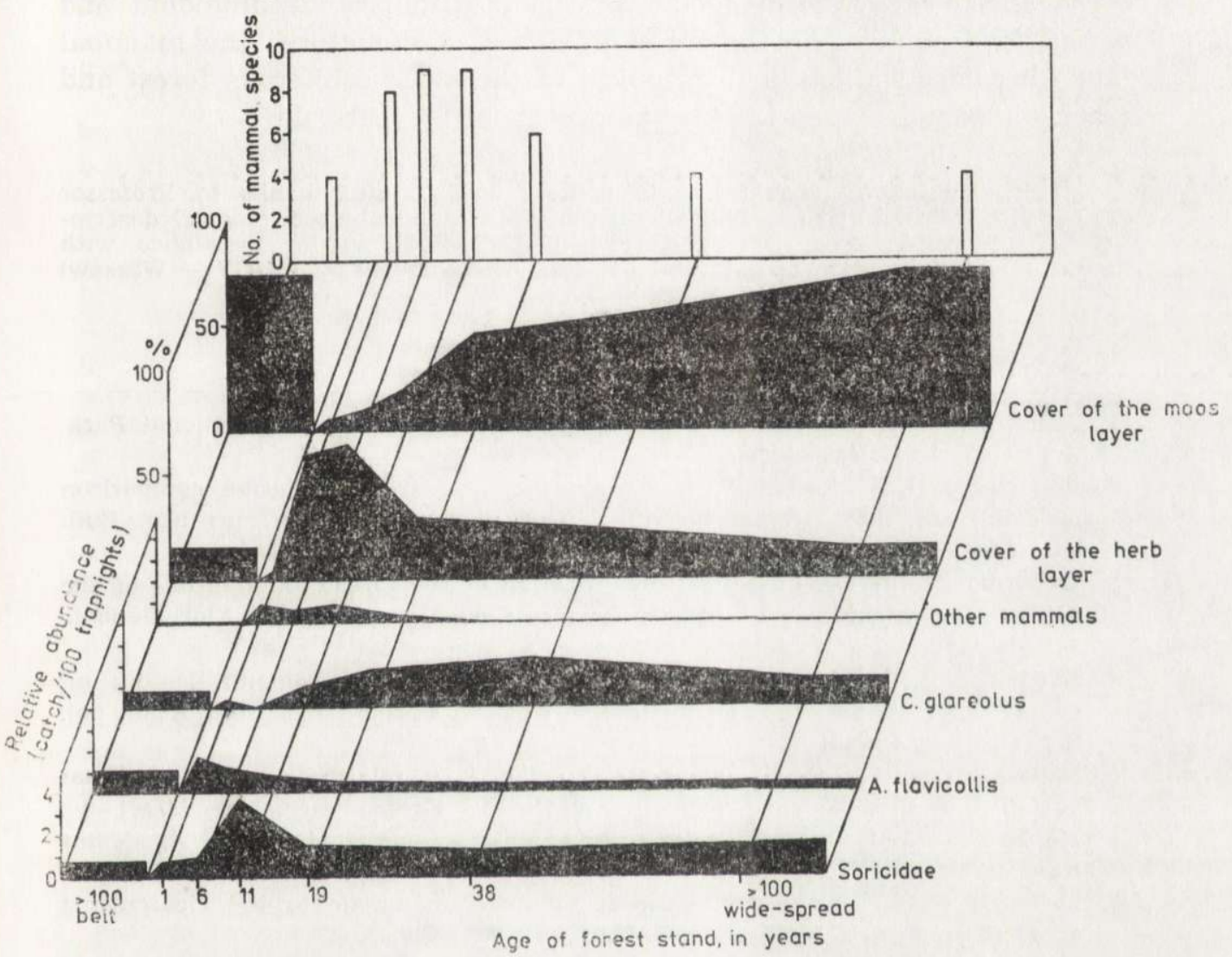

Fig. 6. Relation between numbers of small mammals and vegetation cover of the area in coniferous stands of different age.

as of great importance to management of the natural resources of the Białowieża Primeval Forest. Although the same species occur there, the percentages they form are different and a result of arranging treestands according to the index of similarity of occurrence of mammals is alternative placing of the mammal community of the belt of old stand and the wide-spread old stand. Deformation of the fauna in the timber stand thus begins even before clearing has starțed, 
The clear cut area and the youngest tree plantation form places for entry for species not typical of coniferous forests, but characteristic of agricultural habitats. Young tree plantations from 11-14 years old were found to be richest in respect both of number of species (9) and numbers of individuals. They form the habitat of both forest and meadow - field species, e.g., $M$. arvalis, $M$. agrestis, and $S$. betulina. The luxuriant herb layer, not as yet shaded by trees, and uprooted tree roots in the phase of advanced decay, form good shelter and also provide abundant and varied food supply. As the treestand grows and matures the mammal fauna becomes similar to that typical of the older coniferous forest and reaches this stage when the treestand is about 20 years old.

Acknowledgments: We should like to express our grateful thanks to Professor dr. A. W. Sokolowski (IBL - Białowieża) for the detailed phytosociological description of the study area, Dr. J. Kozłowski (UJ-Kraków) for assistance with mathematical elaboration of data and Dr. hab. R. Andrzejewski (SGGW - Warsaw) for his advice in interpretation of results.

\section{REFERENCES}

1. Aulak W., 1970: Small mammal communities of the Białowieża National Park. Acta theriol., 15: 465-515.

2. Banach A., Kozakiewicz A. \& Kozakiewicz M., 1980: Tentative comparison of small mammal communities in a poor pine stand of various age. Bull. Acad. pol. Sci., Cl. II, 28, 1/2: 43-48.

3. Dzwonko Z., 1977: A numerical classification of the forest communities of the Słonne Góry Mountains (the Polish Eastern Carpathians). Fragm. Flor. Geobot., 23: $345-353$.

4. Grodziński W., 1958: The succesion of small mammal communities on an overgrown clearing and landslip in the Western Carpathians. Bull. Acad. pol. Sci., Cl. II, 6, 10: 431-439.

5. Hansson L., 1978: Small mammal abundance in relation to environmental variables in three Swedish forest phases. Studia Forestalia Suecica, 147: 1-40.

6. Hoffmeyer I., 1973: Internaction and habitat selection in mice Apodemus flavicollis and A. sylvaticus. Oikos, 24: 108--116.

7. Kirkland G. L., Jr., 1977: Responses of small mammals to the clearcutting of northern Appalachian forest. J. Mam., 58: 600-609.

8. Miller D. H. \& Getz L. L., 1977: Factors influencing local distribution and species diversity of forest small mammals in New England, USA. Can. J. Zool., 55: 806-814.

9. Sneath P. H. A. \& Sokal R. R., 1973: Numerical taxonomy. The principles and practice of numerical classification. Freeman: 1-573. San Francisco.

10. Sokołowski A. W., 1961: Mikroklimatische Untersuchungen auf einer Schlagfläche im Urwald von Białowieża. Ekol, pol., A, 9: 259-185.

11. Wolk E. \& Wolk K., 1979: Mysz zaroślowa, Apodemus sylvaticus (L.) nowy gatunek w Puszczy Białowieskiej. Przegl. zool., 23: 80-83. 
Elżbieta WOŁK i Krzysztof WOŁK

\author{
REAKCJE DROBNYCH SSAKOW NA GOSPODARKE LESNA \\ W PUSZCZY BIAEOWIESKIEJ
}

Streszczenie

$\mathrm{Na} 14$ hektarach wiekowo zróżnicowanego boru mieszanego (6 klas wieku) przeprowadzono we wrześniu lat 1976-1979 dziesięciodniowy wyłów drobnych ssaków za pomocą 210 pułapek, umieszczonych w 105 punktach. Linie pułapek przebiegały granicami i środkiem pasa lasu danej klasy wiekowej (Ryc. 1).

Obliczono wskaźnik łowności dla każdej pułapkolinii (liczba złowień/100 pułapkodni) oraz wskaźnik podobieństwa między poszczególnymi pułapkoliniami (wg Sneath \& Sokal, 1973)

Wariant 1 uporządkowania wg wskaźnika podobieństwa, który uwzględnia rezultaty odlowów na wszystkich pułapkoliniach z lat 1977-1979, wyłonił dwie grupy środowisk ugrupowań ssaków. Do najpodobniejszych należą: ugrupowania bytujące w litym starodrzewiu naturalnym oraz wnętrzach sadzonych drzewostanów najstarszych klas wiekowych i wenętrznych pograniczach tych drzewostanów. Występują tu 4 gatunki ssaków, stanowiące $97 \%$ wszystkich złowionych osobników. Ugrupowania ssaków, bytujące w pozostałych środowiskach, stanowią grupę o mniejszym podobieństwie, charakteryzują się większą liczbą gatunków i ich innym składem procentowym (Tabela 3, Ryc. 4). Wariant 2 (wyniki odłowów z lat 1976-1979 na pułapkoliniach prowadzących przez wnętrza drzewostanów) również rozdzielił dane na dwie grupy: o wysokim wskaźniku podobieństwa - ssaki litego starodrzewu i dwu najstarszych klas sadzonego lasu oraz o niskim wskaźniku podobieństwa - ssaki pozostałych środowisk (Tabela 3, Ryc. 4). Tak więc w obu wariantach naturalny starodrzew wyspowy znalazł się w przeciwnej grupie, niż lity starodrzew, co świadczy o istotnych zmianach w ugrupowaniu ssaków starodrzewu o zbyt małej powierzchni.

Sukcesja ssaków na zrębie zupełnym w Puszczy Białowieskiej trwa krócej, niż dojrzewanie drzewostanu i kończy się około dwudziestego roku życia sadzonego drzewostanu. Odbywa się ona w dwu fazach: 1) 1 do 14 lat od zalesienia zrębu, rozpoczyna się niemal zerową liczebnością ssaków na czystym zrębie. Następnie osiedla się wiele gatunków, także nieleśnych, a pod koniec tego okresu występuje maksymalna liczba gatunków i osobników. Młodniki około dziesięcioletnie są na.bogatsze w ssaki, czego przyczyną jest najprawdopodobniej bogato rozwinięte i niezbyt jeszcze ocienione runo (Ryc. 6). (2) 15 do około 20 lat od zalesienia zrębu; zanikają gatunki pierwszej fazy sukcesji i formują się proporcje ilościowe poszczególnych gatunków typowe dla starego boru, co jest związane głównie z wzrostem zacienienia dna lasu (Tabela 4, Ryc. 5). W naturalnym starodrzewiu borowym (ponad 100-letnim) stwierdzono następujące 4 gatunki drobnych ssaków Clethrionomys glareolus, Sorex araneus, Sorex minutus, Apodemus flavicollis. 